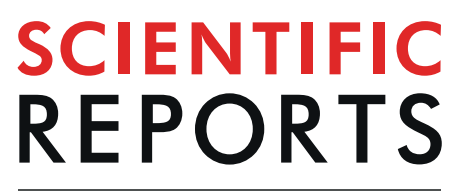

natureresearch

\title{
OPEN Genetic structure and population connectivity of the blue and red shrimp Aristeus antennatus
}

Received: 11 January 2019

Accepted: 20 August 2019

Published online: 19 September 2019
Sandra Heras ${ }^{1}$, Laia Planella ${ }^{1}$, José-Luis García-Marín ${ }^{1}$, Manuel Vera $\mathbb{C}^{1,2}$ \& María Inés Roldán $\mathbb{( i b}^{1}$

The blue and red shrimp Aristeus antennatus is a demersal marine species harvested by bottom trawling in the Mediterranean Sea, the adjacent Atlantic Ocean (AO) waters, and the Mozambique Channel in the Indian Ocean (IO). As it is considered to be a priority species for sustainable fishing, identification of its genetic stocks and the connectivity between them is essential. Using 12 microsatellite loci we detected at least four genetic stocks distributed in the Western Mediterranean (WM), Eastern Mediterranean (EM), AO, and 10 and signals for a possible fifth stock in the Alborán Sea. We detected no additional population structuring within the WM. Thus, although the Almeria-Orán Front exerts some isolating effect, high genetic homogeneity and gene flow are present within the WM Basin. The $1 O$ stock is genetically closer to the $A O$ stock than to the others; thus, the species dispersion route is more likely via the Atlantic Ocean than via the Red Sea. Large effective population sizes suggest population sustainability, but moderate genetic diversity values indicate to proceed with caution. Our genetic results serve as a basis for species conservation to ensure long-term sustainability of this marine resource.

The blue and red shrimp Aristeus antennatus (Risso, 1816) (Penaeoidea, Aristeidae) is a demersal marine decapod that inhabits the muddy bottoms of the continental slope along submarine canyons ${ }^{1}$. The species is distributed throughout the Mediterranean Sea, in the Atlantic Ocean (AO) waters adjacent to the Strait of Gibraltar from Portugal to Cape Verde, and in the western Indian Ocean (IO) from South Africa across the Mozambique Channel, Zanzibar, and the Maldives Islands; more recently, its presence off the coast of Brazil has been suggested $^{2}$. Biological studies indicate that this species is the most eurybathic in the Mediterranean Sea, present at depths ranging from 80 to $3,300 \mathrm{~m}$, with a greater abundance in the first $1,000 \mathrm{~m}$ depth, where fishing occurs ${ }^{3}$.

A. antennatus is among the most important demersal resources for bottom-trawling fishery in the Mediterranean Sea, with 1,782 tonnes collected in $2014^{4}$. In fact, since 2006, the General Fisheries Commission for the Mediterranean Sea included A. antennatus on the list of priority species for which fishing regulation plans should be developed ${ }^{5}$. It is highly appreciated gastronomically and retail market prices are quite high (\$70-160/ $\mathrm{kg}$ ) in the Western Mediterranean (WM), where it has been fished most intensely. Outside the Mediterranean Sea, other fishing zones of lesser importance extend to the south of Portugal ${ }^{6}$, and a new fishing ground was established recently in the Mozambique Channel ${ }^{7}$.

However, no sustainable fishing management policy for A. antennatus exists at the international level yet. Long-term species sustainability requires adequate fishing and conservation strategies that depend heavily on the identification of the species' population structure. One of the primary tools for this purpose is genetic analysis, which involves the identification of genetic stocks and connectivity among them ${ }^{8}$. Such analysis is particularly important to study population processes of marine organisms from inaccessible habitats, such as deep-sea species ${ }^{9}$.

A previous study using two mitochondrial DNA (mtDNA) markers (16S rDNA and COI) detected four genetic stocks of $A$. antennatus in the range of distribution where the species is exploited: the AO, WM, Eastern Mediterranean (EM), and $\mathrm{IO}^{2}$. However, no mtDNA marker study to date has been able to discern genetic structuring at a more regional level between proximal fishing zones, ${ }^{2,10-12}$.

A priori, the examination of more variable molecular markers, such as microsatellites, which are sensitive to small but significant genetic differences, should reveal genetic structure at a finer regional scale in populations of

${ }^{1}$ Laboratori d'Ictiologia Genètica, Universitat de Girona, Girona, Spain. ${ }^{2}$ Present address: Departamento de Zoología, Genética y Antropología Física, Campus Lugo, Universidade de Santiago de Compostela, Lugo, Spain. Correspondence and requests for materials should be addressed to M.I.R. (email: marina.roldan@udg.edu) 


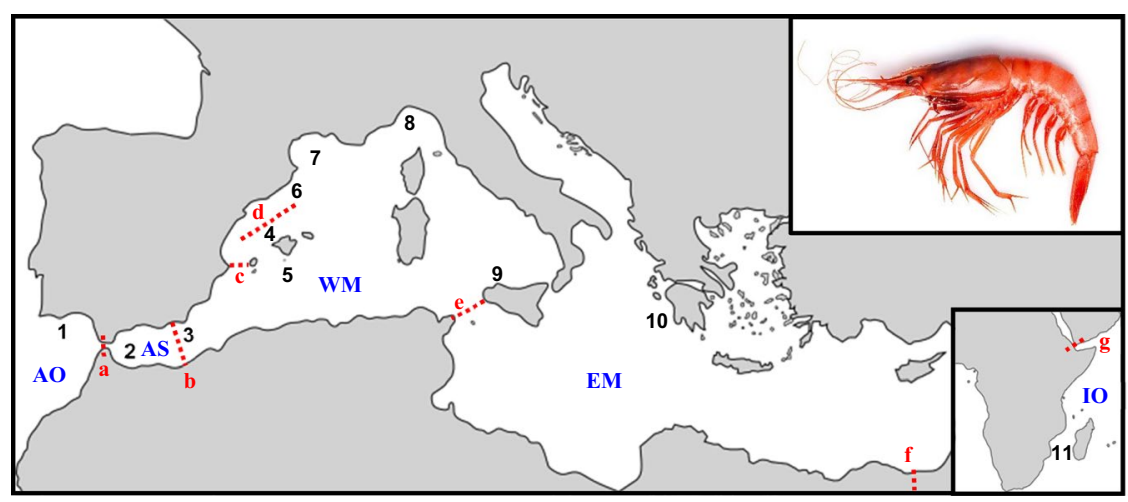

Figure 1. Main geographic and oceanographic barriers in the Mediterranean Sea and Red Sea. Sampling locations of A. antennatus in the five analysed regions: Atlantic Ocean (AO): 1 Faro; Alborán Sea (AS): 2 Alborán Sea; Western Mediterranean (WM): 3 Almería, 4 Sóller, 5 Cabrera, 6 Palamós, 7 Gulf of Lion, 8 Genoa, 9 Palermo; Eastern Mediterranean (EM): 10 Ionian Sea; Indian Ocean (IO): 11 Mozambique Channel. Main geographic and oceanographic barriers in the Mediterranean Sea and Red Sea are represented with dashed lines: (a) Strait of Gibraltar, (b) Almería-Orán Front, (c) Ibiza Channel, (d) Balearic Front, (e) Strait of Sicily, (f) Suez Canal, (g) Strait of Bab-el-Mandeb.

A. antennatus and the degree of connectivity between stocks. Microsatellite analysis has enabled the identification of stocks in other penaeoid marine shrimp species (reviewed in Heras et al. ${ }^{13}$ ). However, very few microsatellite markers are available for A. antennatus (14 are reported in Cannas et al. ${ }^{14}$ ), and they have not been proven to be useful for the detection of genetic stocks ${ }^{15}$. This situation led us to develop and characterise 35 new microsatellite loci for A. antennatus using next-generation sequencing ${ }^{13}$ and in the present study we used 12 of them.

Although human impacts, particularly through fishing ${ }^{16}$, affect the population configuration of marine organisms, other factors such as marine geology and ocean currents create many geographic and oceanographic discontinuities that can reduce connectivity, and strongly influence population structure affecting effective species conservation strategies, as has been observed in numerous Mediterranean species (reviewed by Patarnello et al. ${ }^{17}$ and Pascual et al. ${ }^{18}$ ). In the Mediterranean Sea, they include the following (Fig. 1):

(i) The Strait of Gibraltar, which forms the dividing zone between the denser Mediterranean waters and the Atlantic Ocean waters.

(ii) The Almería-Orán Front, formed at the eastern end of the anticyclonic Eastern Alborán Gyre, between the coasts of the Iberian Peninsula and Algeria.

(iii) The Balearic Front and Ibiza Channel, which act in the area between the Balearic Islands and the Iberian Peninsula.

(iv) The Strait of Sicily separating the Western Mediterranean Basin from the Eastern Mediterranean Basin.

On the other hand, the Red Sea is a possible connection between the Indian Ocean and the Mediterranean Sea, but the Bab-el-Mandeb Strait and the Suez Canal are possible barriers along this route (Fig. 1).

By using genetic variation at 12 microsatellite loci, the aim of this study is the identification of genetic stocks across the distribution of $A$. antennatus and the effect of putative geographic and oceanographic barriers, indicated before, to prevent connectivity among stocks.

\section{Results}

Genetic diversity and effective population size. The 12 microsatellite loci were polymorphic at all locations analysed and presented a total of 158 alleles, with an average of 13.2 (range, 4-40) alleles per locus, of which $19 \%(n=30)$ were private alleles present at single locations. Among five sampled regions, Mozambique contributed the largest number of alleles ( $\mathrm{Ap}=17$; Table 1). Genotype linkage disequilibrium was not detected in any pair of loci across the 11 sampled locations.

Analysis of variability and genetic diversity by location yielded moderate values, with an average of 7.8 (range, 7.1-9.8) alleles per locus, average allelic richness (Ar) value of 7.5 (range, 6.9-9.1), and mean observed and expected heterozygosities (Ho and $H e$, respectively) of 0.458 (range, 0.406-0.522) and 0.628 (range, 0.603-0.684), respectively. Mozambique sample presented the highest values in all cases (Table 1).

Among the 12 microsatellite loci only Aa496b and Aa1195 complied with HW equilibrium genotype proportions at all locations (Supplementary Table S1). On average, all locations showed deviation from Hardy-Weinberg (HW) equilibrium related with positive $F_{\text {IS }}$ values, suggesting a deficit of heterozygotes (Table 1). The observed heterozygote deficit might be due to the presence of null alleles. With the exception of the Aa1195 locus, Micro-Checker analysis suggested the presence of null alleles at the other loci in at least one sample (with a maximum allele frequency of 0.2893 at Aa818 locus in Palermo), but never the same loci across locations. Given the lack of consistency among locations in the presence of null alleles, all loci were included in further analysis.

The estimates of effective population size $\left(N_{e}\right)$ using NeEstimator software often yielded negative values that were interpreted as very large (infinite; Table 1$)^{19}$. Finite values were obtained only for Faro, Alborán, and Cabrera 


\begin{tabular}{|l|l|l|l|l|l|l|l|l|l|l|}
\hline Region and Sample Location & Code & $\boldsymbol{N}$ & $\mathbf{N a}$ & $\mathbf{A r}$ & $\mathbf{A p}$ & $\mathbf{H o}$ & $\mathbf{H e}$ & $\boldsymbol{F}_{\text {IS }}$ & $\boldsymbol{N}_{\boldsymbol{e}}$ & $\mathbf{C I}$ for $\boldsymbol{N}_{\boldsymbol{e}}$ \\
\hline Atlantic Ocean & $\mathrm{AO}$ & & & & & & & & & \\
\hline Faro, Portugal & $\mathrm{Fa}$ & 38 & 7.6 & 7.6 & 1 & 0.435 & 0.628 & 0.307 & 241.0 & 88.0 -infinite \\
\hline Alborán Sea & $\mathrm{AS}$ & & & & & & & & & \\
\hline Alborán Sea, Spain & $\mathrm{Alb}$ & 53 & 8.0 & 7.4 & 0 & 0.413 & 0.620 & 0.333 & $21,464.7$ & 198.5 -infinite \\
\hline Western Mediterranean & $\mathrm{WM}$ & & & & & & & & & \\
\hline Almería, Spain & $\mathrm{Al}$ & 45 & 7.3 & 7.1 & 1 & 0.480 & 0.624 & 0.231 & Infinite & 131.9 -infinite \\
\hline Sóller, Spain & $\mathrm{So}$ & 47 & 8.0 & 7.5 & 3 & 0.466 & 0.641 & 0.273 & Infinite & 163.9 -infinite \\
\hline Cabrera, Spain & $\mathrm{Ca}$ & 40 & 7.4 & 7.3 & 1 & 0.496 & 0.632 & 0.216 & $4,121.8$ & 147.8 -infinite \\
\hline Palamós, Spain & $\mathrm{Pa}$ & 49 & 7.3 & 6.9 & 1 & 0.406 & 0.603 & 0.327 & Infinite & 992.8 -infinite \\
\hline Gulf of Lion, France & $\mathrm{GL}$ & 50 & 8.3 & 7.7 & 3 & 0.442 & 0.619 & 0.286 & Infinite & 474.9 -infinite \\
\hline Genoa, Italy & $\mathrm{Ge}$ & 44 & 7.5 & 7.2 & 0 & 0.491 & 0.629 & 0.220 & Infinite & 285.7 -infinite \\
\hline Palermo, Italy & $\mathrm{Po}$ & 40 & 7.6 & 7.5 & 2 & 0.442 & 0.614 & 0.277 & Infinite & 108.0 -infinite \\
\hline Eastern Mediterranean & $\mathrm{EM}$ & & & & & & & & & \\
\hline Ionian Sea, Greece & $\mathrm{IS}$ & 40 & 7.1 & 7.0 & 1 & 0.444 & 0.613 & 0.276 & Infinite & 156.4 -infinite \\
\hline Indian Ocean & $\mathrm{IO}$ & & & & & & & & & \\
\hline $\begin{array}{l}\text { Mozambique Channel, } \\
\text { Mozambique }\end{array}$ & Moz & 48 & 9.8 & 9.1 & 17 & 0.522 & 0.684 & 0.237 & Infinite & Infinite-infinite \\
\hline Total/average & & 494 & 7.8 & 7.5 & 2.7 & 0.458 & 0.628 & 0.271 & Infinite & Infinite-infinite \\
\hline
\end{tabular}

Table 1. Genetic diversity and effective population size in eleven Aristeus antennatus locations. N, sample size; $\mathrm{Na}$, number of alleles per locus; Ar, allelic richness per locus (based on minimum sample size of 37 diploid individuals with complete genotypes); Ap, number of private alleles; $\mathrm{Ho}$, observed heterozygosity; $\mathrm{He}$, expected heterozygosity; $F_{\mathrm{IS}}$, inbreeding coefficient; $N_{e}$, effective population size; CI, confidence interval (jack-knife method). All individuals displayed $\geq 11$ genotyped loci.

\begin{tabular}{|l|l|l|l|l|l|l|l|l|l|l|l|l|}
\hline \multicolumn{2}{|c|}{} & AO & AS & \multicolumn{1}{l}{ WM } & \multicolumn{1}{l|}{ EM } & \multicolumn{1}{l|}{ IO } \\
\cline { 2 - 16 } & & Fa & Alb & Al & So & Ca & Pa & GL & Ge & Po & IS & Moz \\
\hline AO & Fa & - & $\mathbf{0 . 0 0 0 0 0}$ & $\mathbf{0 . 0 0 0 0 0}$ & $\mathbf{0 . 0 0 0 0 0}$ & $\mathbf{0 . 0 0 0 0 0}$ & $\mathbf{0 . 0 0 0 0 0}$ & $\mathbf{0 . 0 0 0 1 0}$ & $\mathbf{0 . 0 0 0 1 0}$ & $\mathbf{0 . 0 0 0 0 0}$ & $\mathbf{0 . 0 0 0 3 0}$ & $\mathbf{0 . 0 0 0 0 0}$ \\
\hline AS & Alb & 0.03396 & - & 0.34175 & 0.03782 & 0.38452 & 0.07029 & 0.35412 & 0.76091 & 0.49342 & 0.01049 & $\mathbf{0 . 0 0 0 0 0}$ \\
\hline WM & Al & 0.03448 & 0.00394 & - & 0.02841 & 0.94119 & 0.33482 & 0.23760 & 0.29621 & 0.34719 & 0.00168 & $\mathbf{0 . 0 0 0 0 0}$ \\
\hline & So & 0.04191 & 0.00888 & 0.00963 & - & 0.49134 & 0.08069 & 0.30611 & 0.28859 & 0.01485 & 0.00396 & $\mathbf{0 . 0 0 0 0 0}$ \\
\hline & Ca & 0.03513 & 0.00372 & 0.00000 & 0.00268 & - & 0.50292 & 0.67617 & 0.78764 & 0.49797 & 0.00446 & $\mathbf{0 . 0 0 0 0 0}$ \\
\hline & Pa & 0.03534 & 0.00814 & 0.00410 & 0.00808 & 0.00270 & - & 0.77507 & 0.27067 & 0.19454 & $\mathbf{0 . 0 0 0 3 0}$ & $\mathbf{0 . 0 0 0 0 0}$ \\
\hline & GL & 0.02521 & 0.00392 & 0.00475 & 0.00422 & 0.00106 & 0.00044 & - & 0.99119 & 0.26453 & 0.07643 & $\mathbf{0 . 0 0 0 0 0}$ \\
\hline & Ge & 0.02278 & 0.00061 & 0.00392 & 0.00433 & 0.00000 & 0.00480 & 0.00000 & - & 0.57034 & 0.23760 & $\mathbf{0 . 0 0 0 0 0}$ \\
\hline & Po & 0.03515 & 0.00314 & 0.00399 & 0.01191 & 0.00271 & 0.00633 & 0.00509 & 0.00200 & - & $\mathbf{0 . 0 0 0 1 0}$ & $\mathbf{0 . 0 0 0 0 0}$ \\
\hline EM & IS & 0.02413 & 0.01261 & 0.01582 & 0.01517 & 0.01553 & 0.02158 & 0.00899 & 0.00531 & 0.02443 & - & $\mathbf{0 . 0 0 0 0 0}$ \\
\hline IO & Moz & 0.02892 & 0.04379 & 0.03887 & 0.02910 & 0.03107 & 0.04346 & 0.03296 & 0.02997 & 0.04695 & 0.03578 & - \\
\hline
\end{tabular}

Table 2. Pairwise $F_{\mathrm{ST}}$ values between the 11 sampling sites (below the diagonal) and $p$ values (above the diagonal). Region and location codes are given in Table 1. Significance after Bonferroni correction indicated in bold $(p<0.00091)$.

locations (241.0, 21,464.7 and 4,121.8, respectively), although even in these cases the upper boundaries of the $95 \%$ confidence intervals were infinite (Table 1).

Population structure and gene flow. Pairwise $F_{\mathrm{ST}}$ between all locations in the WM were very low (average, 0.00394 ) and not significant (Table 2). In addition, the AS was not significantly differentiated from the WM locations, indicative of a single population in the Western Mediterranean Sea (WM + AS). Comparative values between the IO and AO regions, respectively, and the other regions were highest (averages, 0.03609 and 0.03170, respectively) and statistically significant. The EM sample exhibited marked and significant differentiation compared with the AO (0.02413) and IO (0.03578), and less differentiation with the WM (average, 0.01526) and Alborán Sea (AS; 0.01261) locations, with significant values obtained only for the Palamós and Palermo samples. In addition, the neighbour-joining (NJ) tree summarised the geographical population groups (Fig. 2) suggested by pairwise $F_{\mathrm{ST}}$ distance analysis.

We confirmed that the frequency of null alleles did not alter our results, as the pairwise $F_{\mathrm{ST}}$ values were similar with and without correction for the presence of null alleles (Supplementary Table S2). Thus, the effect of null alleles was negligible when estimating population genetic differentiation.

Analysis of molecular variance (AMOVA) revealed significant genetic structuring in all hypothesised grouping scenarios, with significant $F_{\mathrm{ST}}$ values due primarily to differences among groups $\left(F_{\mathrm{CT}}\right)$, rather than within 


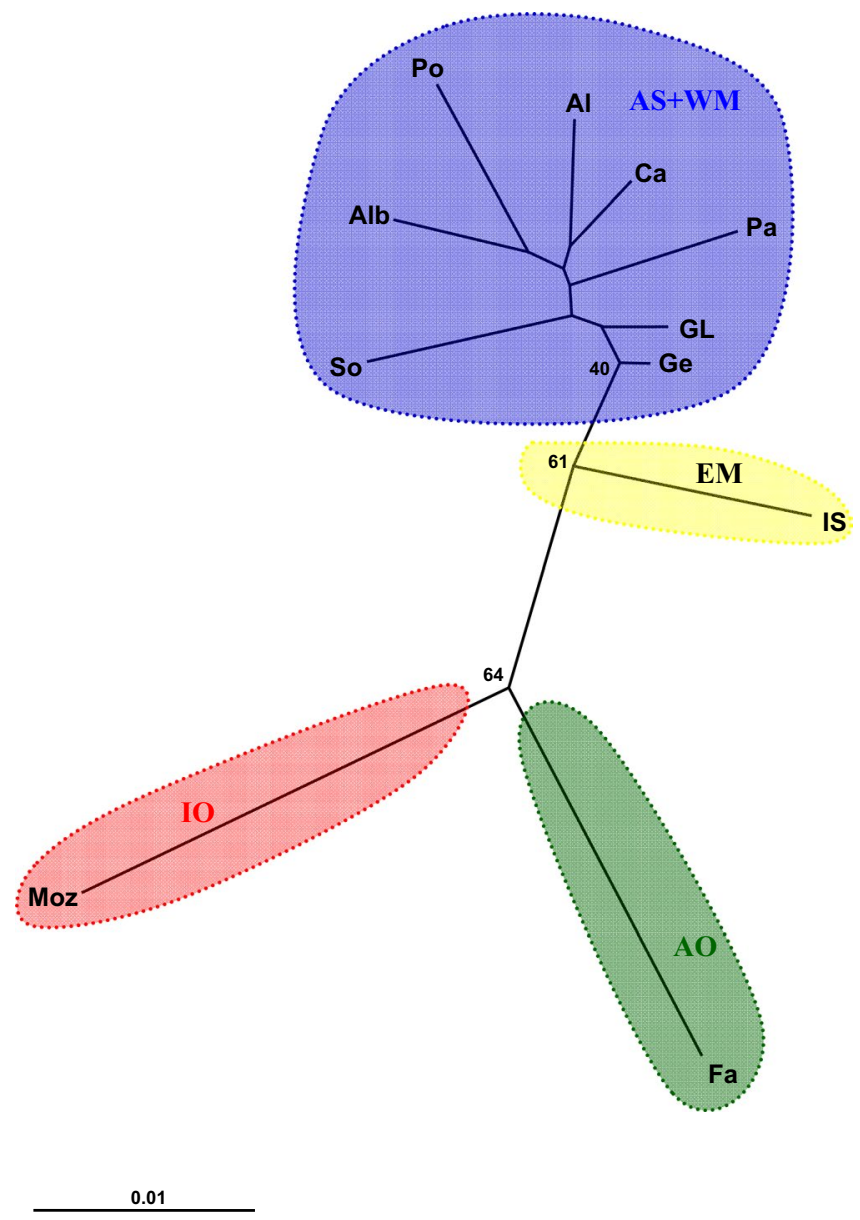

Figure 2. Neighbour-joining tree based on Latter's $F_{\mathrm{ST}}$ genetic distance ${ }^{56} . \geq 40 \%$ bootstrap values based on 1,000 replicates are indicated next to nodes. Region and location codes are given in Table 1.

groups $\left(F_{\mathrm{SC}}\right)$. The first and fourth hypotheses yielded the most significant $F_{\mathrm{CT}}$ values and no significant divergence within groups (Table 3). For the fourth hypothesis (genetic structuring in five groups), the Almería-Orán Front was added to the barriers included in the first one. Similar results were obtained in both analyses, suggesting that genetic structuring in five groups is as plausible as that in four groups, with the Almería-Orán Front possibly contributing to isolate the A. antennatus population in the AS from the WM ones. Compared with the first and fourth hypotheses, which included the Strait of Gibraltar, the second one, in which the Strait of Gibraltar did not act as barrier, showed increased, significant variance among samples within groups $\left(F_{\mathrm{SC}}=0.00898, p<0.00001\right)$ due to the low homogeneity within the groups created (Table 3 ). These results supported the hypothesis that the Strait of Gibraltar acts as an effective barrier for A. antennatus. Similarly, comparison of the third hypothesis with the most plausible first and fourth hypotheses suggested that the Strait of Sicily also acts as an oceanographic barrier for this species $\left(F_{\mathrm{SC}}=0.00623, p=0.00713\right.$; Table 3$)$.

Discriminant analysis of principal components (DAPC) enabled differentiation of four groups: IO (Mozambique), AO (Faro), EM (Ionian Sea), and AS + WM (Fig. 3). The horizontal scatterplot axis, explaining $28.54 \%$ of variance, differentiated individuals from Mozambique; the vertical axis, explaining $17.25 \%$ of variance, differentiated individuals from Faro; and the third axis, explaining $12.94 \%$ of variance, differentiated individuals from the Ionian Sea. The proportion of individuals assigned to locations as inferred from membership probabilities was largest for the location of origin in all cases (Table 4). The highest values were for Mozambique $(0.7708)$ and Faro (0.7368), which showed the least admixture, followed by the Ionian Sea (0.6250), with some admixture, primarily with individuals from AS and WM (Table 4, Supplementary Fig. S3). The AS and WM samples had lower proportions of assignment to their original location, but in general the second highest percentage of assignment was for another location in the same cluster, suggesting admixture between AS and WM populations.

We detected significant correlation between genetic and geographical distances for both: the Atlantic route $(r=0.67579, p=0.00842)$ and the Red Sea route $(r=0.6502, p=0.00783$; Supplementary Fig. S4). The correlation still held when Mozambique, the most distant sample, was excluded from the analysis $(r=0.31811, p=0.03937$; Supplementary Fig. S4). However, when we eliminated Mozambique and EM, the second most distant sample located beyond the possible oceanographic barrier of the Strait of Sicily, the result was not significant $(r=0.3257$, $p=0.07339$ ). When we excluded Mozambique and Faro (AO), which is located on the other side of the Strait of Gibraltar, but retained the EM sample, again a significant correlation was obtained $(r=0.4057, p=0.02401)$, indicating a pattern of isolation by distance (IBD) along the Mediterranean Sea. 


\begin{tabular}{|c|c|c|c|}
\hline Hypothesis & Variance & $\%$ Variation & F statistics \\
\hline \multicolumn{4}{|c|}{$\begin{array}{l}\text { 1. Four groups (mtDNA: Strait of Gibraltar and Strait of Sicily acting) } \\
\text { AO, AS + WM, EM, IO }\end{array}$} \\
\hline Among groups & 0.09986 & 2.58 & $F_{\mathrm{CT}}=0.02577 * * *$ \\
\hline Among samples within groups & 0.01524 & 0.39 & $F_{\mathrm{SC}}=0.00404$ \\
\hline Within samples & 3.75983 & 97.03 & $F_{\mathrm{ST}}=0.02970 * * *$ \\
\hline \multicolumn{4}{|c|}{$\begin{array}{l}\text { 2. Four groups (mtDNA; + Almería-Orán Front, Strait of Gibraltar not acting) } \\
\text { AO }+ \text { AS, WM, EM, IO }\end{array}$} \\
\hline Among groups & 0.04631 & 1.20 & $F_{\mathrm{CT}}=0.01206^{* *}$ \\
\hline Among samples within groups & 0.03406 & 0.89 & $F_{\mathrm{SC}}=0.00898 * * *$ \\
\hline Within samples & 3.75983 & 97.91 & $F_{\mathrm{ST}}=0.01206^{* * *}$ \\
\hline \multicolumn{4}{|c|}{$\begin{array}{l}\text { 3. Four groups (mtDNA; Strait of Sicily not acting) } \\
\text { AO, AS + WM, Po + EM, IO }\end{array}$} \\
\hline Among groups & 0.06708 & 1.74 & $F_{\mathrm{CT}}=0.01742 * * *$ \\
\hline Among samples within groups & 0.02356 & 0.61 & $F_{\mathrm{SC}}=0.00623 * *$ \\
\hline Within samples & 3.75983 & 97.65 & $F_{\mathrm{ST}}=0.02354^{* * *}$ \\
\hline \multicolumn{4}{|c|}{$\begin{array}{l}\text { 4. Five groups (mtDNA; + Almería-Orán Front) } \\
\text { AO, AS, WM, EM, IO }\end{array}$} \\
\hline Among groups & 0.07711 & 2.00 & $F_{\mathrm{CT}}=0.02002 * * *$ \\
\hline Among samples within groups & 0.01421 & 0.37 & $F_{\mathrm{SC}}=0.00377$ \\
\hline Within samples & 3.75983 & 97.63 & $F_{\mathrm{ST}}=0.02371 * * *$ \\
\hline
\end{tabular}

Table 3. Hierarchical analysis of molecular variance (AMOVA) based on different grouping hypotheses. Region and location codes are given in Table 1. MtDNA (four groups based on previous mitochondrial DNA study by Fernández et al. $\left.{ }^{10}\right)$. ** $p<0.01, * * * p<0.001$.

The migration network showed the greatest relative gene flow among WM Basin nodes (WM, AS, Palermo, and Almería) (Fig. 4), which agreed with the lower genetic differentiation observed among these locations (Table 2). The EM node was closest to the other Mediterranean nodes, with no relevant gene flow with the IO node. The AO and $\mathrm{IO}$ were the most distant regions (with the AO closer to the Mediterranean than the IO), as indicated by their lower relative rates of migration. We found no significant evidence of asymmetric gene flow between nodes.

\section{Discussion}

Our analysis yielded higher average Na values (7.8; Table 1) than reported previously for the same loci by Heras et al. ${ }^{13}$, likely because of higher sample size in the present study. Our overall median Ho and He values (0.458 and 0.628; Table 1) were in the range of other reports for A. antennatus ${ }^{13,14}$ and the related Aristaeomorpha foliacea (Aristeidae) ${ }^{20}$. The Mozambique sample presented the highest levels of diversity ( $\mathrm{Na}, \mathrm{Ar}, \mathrm{Ho}$, and $\mathrm{He}$ in Table 1), followed by the Atlantic sample and then the Mediterranean ones, which suggests that the origin of $A$. antennatus is outside the Mediterranean Sea. The majority of species currently found in the Mediterranean Sea are likely the result of colonisation from the Atlantic Ocean, due to the tectonic opening of the Strait of Gibraltar after 0.5 million years of the Messinian Salinity Crisis (5.9-5.3 Ma), and to a much lesser degree from the Red Sea ${ }^{17,21}$.

The heterozygote deficit, reflected in positive $F_{\text {IS }}$ values (average $=0.271$; Table 1 ), was responsible for the observed HW deviations. We ruled out possible inbreeding, as a recent study suggested that spawning groups of this species are formed mostly by unrelated individuals ${ }^{22}$. We believe that this deficit may be due to the null alleles as previously observed for A. antennatus and other decapods ${ }^{13,15}$ and in the case of WM, they could also be due to the Wahlund effect.

The $N_{e}$ is an indicator of population viability and should not fall below 50 , as was observed in our study (Table 1), to avoid population extinction from inbreeding depression ${ }^{23}$. Thus, although A. antennatus is subject to intensive fishing, which is lower in Mozambique as suggested by the very large (infinite) lower limit of CI, the risk of demographic reduction due to inbreeding is low. Nevertheless, as estimates of genetic diversity at our study were not particularly high, caution is warranted because overfishing could result in the loss of essential alleles for adaptation to environmental changes ${ }^{16}$.

The $F_{\mathrm{ST}}$ values obtained in our study may appear to be low, but they were significant among the principal groups detected (Table 2). Low $F_{\mathrm{ST}}$ values, even those lower than 0.01 , are common in marine species ${ }^{24}$, and high $N_{e}$, as detected in our study, can lead to low degrees of genetic differentiation in neutral markers such as microsatellites $^{25}$. A study on decapod crustaceans suggested that species inhabiting deeper waters, such as A. antennatus, present lower genetic differentiation than those in shallower waters ${ }^{26}$. We detected at least four genetic stocks across the distribution of A. antennatus, consisting of the AO, WM, EM, and IO stocks (Tables 2, 3, Figs 2, 3). This result agrees with the previously reported genetic structure of the species from mtDNA variation ${ }^{2}$. However, with the use of more sensitive markers, we revealed a possible new fifth genetic stock, the AS (Table 3).

A recent study showed that Mediterranean marine species, including crustaceans, with moderate or elevated dispersal capacity [planktonic larval duration (PLD) $>2$ weeks] are significantly affected by oceanographic discontinuities that reduce gene flow between populations ${ }^{18}$. The estimated PLD of $A$. foliacea could exceed 3 


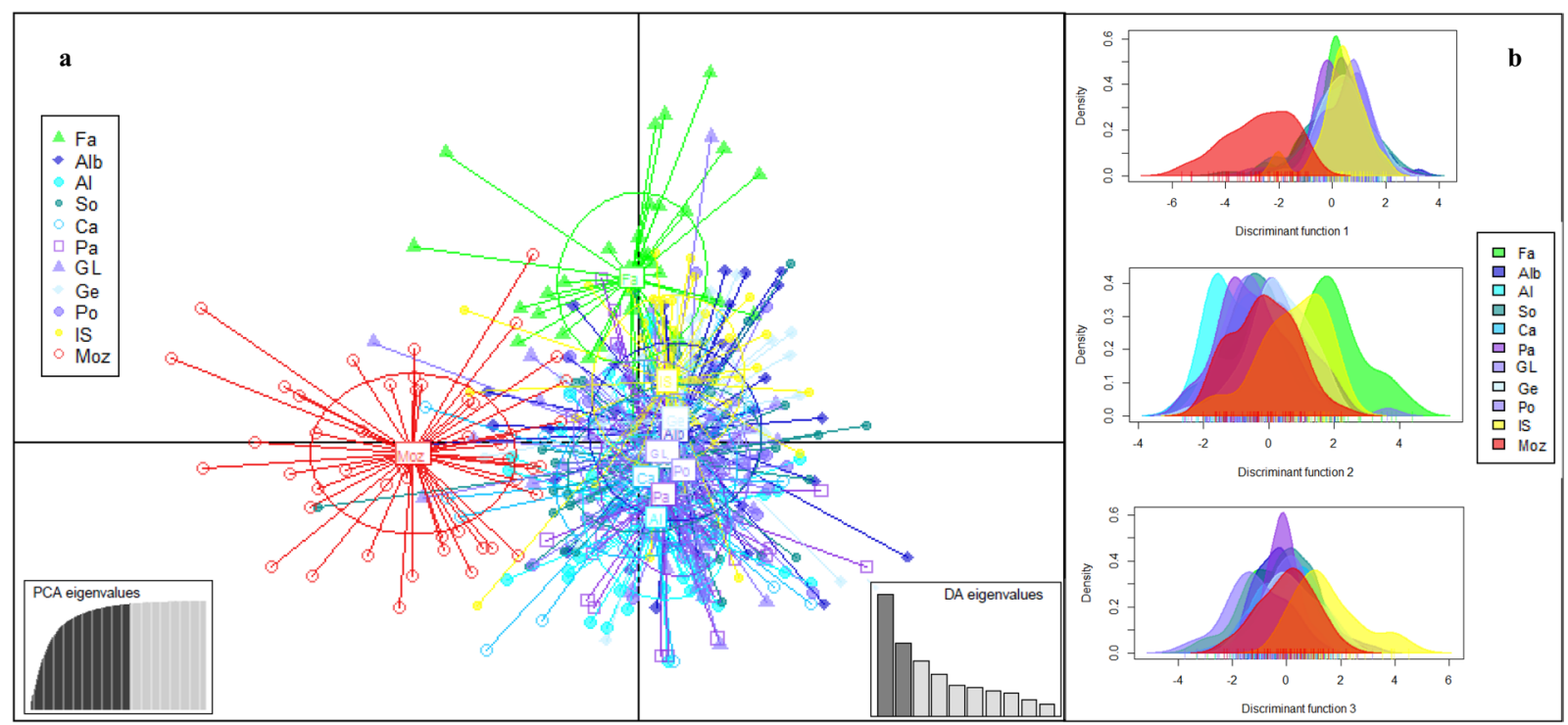

Figure 3. Discriminant analysis of principal components (DAPC) results. (a) Scatterplot showing the first two principal components from DAPC. Individuals are represented as symbols and groups derived from locations as inertia ellipses. The eigenvalues retained in principal component analysis (PCA) and discriminant analysis (DA) are indicated. (b) Individual density plots for the three first discriminant functions. Each colour represents a location. Location codes are given in Table 1.

\begin{tabular}{|c|c|c|c|c|c|c|c|c|c|c|c|}
\hline \multirow{2}{*}{$\begin{array}{l}\text { Original } \\
\text { location }\end{array}$} & \multicolumn{11}{|c|}{ Assigned location } \\
\hline & $\mathbf{F a}$ & Alb & Al & So & $\mathrm{Ca}$ & $\mathbf{P a}$ & GL & $\mathrm{Ge}$ & Po & IS & Moz \\
\hline $\mathrm{Fa}$ & 0.7368 & 0.1315 & 0.0000 & 0.0000 & 0.0000 & 0.0263 & 0.0000 & 0.0263 & 0.0263 & 0.0263 & 0.0263 \\
\hline Alb & 0.0188 & 0.5471 & 0.0188 & 0.0000 & 0.0566 & 0.0377 & 0.0377 & 0.0566 & 0.1132 & 0.0750 & 0.0377 \\
\hline $\mathrm{Al}$ & 0.0444 & 0.0222 & 0.5330 & 0.0666 & 0.0666 & 0.1110 & 0.0222 & 0.0222 & 0.0444 & 0.0444 & 0.0222 \\
\hline So & 0.0000 & 0.0850 & 0.0638 & 0.5106 & 0.0638 & 0.1063 & 0.0212 & 0.0638 & 0.0426 & 0.0212 & 0.0212 \\
\hline $\mathrm{Ca}$ & 0.0000 & 0.0250 & 0.1000 & 0.0500 & 0.3500 & 0.0750 & 0.0750 & 0.1000 & 0.1000 & 0.0500 & 0.0750 \\
\hline $\mathrm{Pa}$ & 0.0612 & 0.0204 & 0.0816 & 0.0204 & 0.0408 & \begin{tabular}{|l|}
0.5102 \\
\end{tabular} & 0.0612 & 0.0408 & 0.0612 & 0.0612 & 0.0204 \\
\hline GL & 0.0800 & 0.0400 & 0.0200 & 0.0600 & 0.0200 & 0.0600 & 0.5200 & 0.0600 & 0.0600 & 0.0400 & 0.0400 \\
\hline $\mathrm{Ge}$ & 0.0227 & 0.1590 & 0.0227 & 0.0455 & 0.0227 & 0.1590 & 0.0227 & 0.3181 & 0.0909 & 0.1136 & 0.0227 \\
\hline Po & 0.0750 & 0.1500 & 0.0250 & 0.0500 & 0.0500 & 0.0500 & 0.0750 & 0.0000 & 0.4500 & 0.0750 & 0.0000 \\
\hline IS & 0.0250 & 0.0000 & 0.0750 & 0.0500 & 0.0250 & 0.0000 & 0.0500 & 0.1000 & 0.0000 & 0.6250 & 0.0500 \\
\hline $\mathrm{Moz}$ & 0.0625 & 0.0417 & 0.0417 & 0.0000 & 0.0000 & 0.0208 & 0.0208 & 0.0000 & 0.0000 & 0.0417 & 0.7708 \\
\hline
\end{tabular}

Table 4. Proportions of individuals assigned to their original locations (in bold) and to other locations. Location codes are given in Table 1.

weeks ${ }^{27}$, thus, through extrapolation to $A$. antennatus, whose larval duration is still unknown, we can infer that the species likewise would be affected by such discontinuities.

The observed genetic differentiation of A. antennatus between the $\mathrm{AO}$ and Mediterranean Sea (Table 2, Figs 2, 3, 4) fits the phylogeographic pattern detected in the majority of Mediterranean marine species, including decapods ${ }^{17,28-31}$. According to a review ${ }^{18}$, the Strait of Gibraltar is the present-day biogeographic barrier that acts most strongly to reduce gene flow between North Atlantic and Mediterranean populations, also affecting decapods ${ }^{26}$. Based on our findings, it is the primary discontinuity marking the Atlantic-Mediterranean transition for A. antennatus, as detected previously with mtDNA analyses ${ }^{2,12}$. These results differ from the conclusions of Lo Brutto et al. ${ }^{32}$ using mtDNA and amplified fragment length polymorphisms (AFLPs) in A. antennatus, as they reported no significant genetic variation between the Atlantic and the Mediterranean populations. Considering that the depth of maximum abundance of $A$. antennatus adults $(600-800 \mathrm{~m})^{3}$ falls below the maximum sill depth in the Strait of Gibraltar $(284 \mathrm{~m} \text { at a width of } \sim 30 \mathrm{~km})^{21}$, the dispersal of adults is restricted, although possible planktonic larval drift by surface currents would not ${ }^{33-36}$.

Previous mtDNA analyses failed to identify the Almería-Orán Front as a barrier between populations of A. antennatus ${ }^{2}$. However, our results indicated a slight isolation of the AS sample from the other WM samples (Table 3), despite the gene flow suggested between them (Fig. 4). The size, position, and intensity of this front are variable and depend primarily on the Eastern Alborán Gyre, which collapses and gradually regenerates with a periodicity of 4 weeks ${ }^{37}$. Therefore, the semi-permanent and variable nature of the front helps to explain the tenuous effect we observed. The mtDNA analyses have shown that the Almería-Orán Front affects some crustacean 


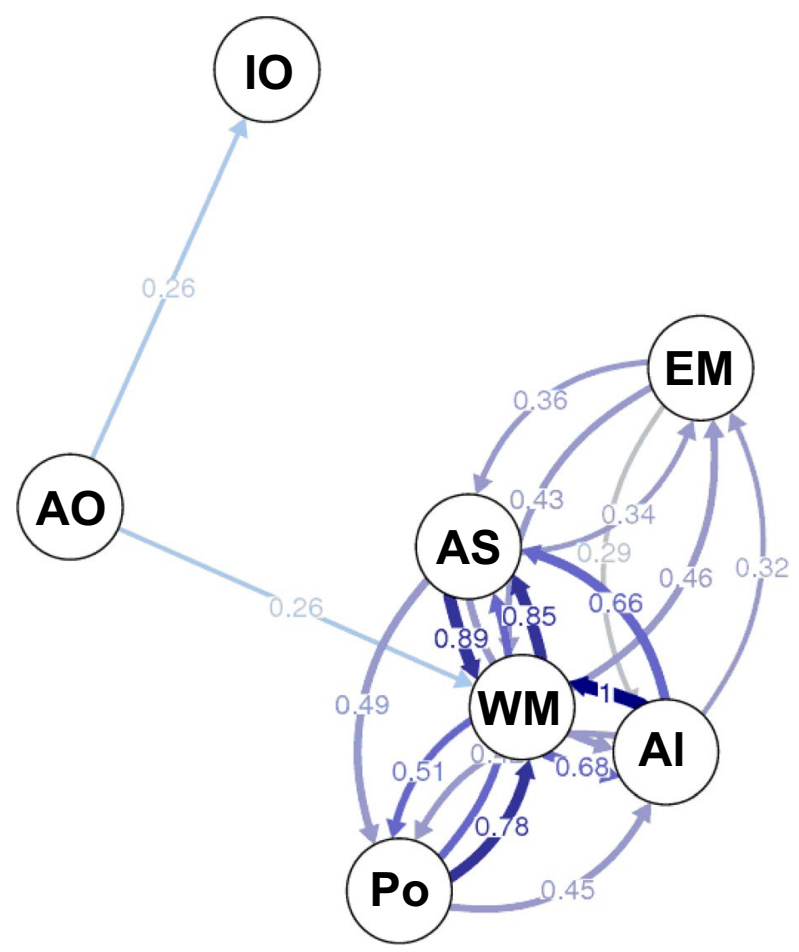

Figure 4. Relative migration network created using $\mathrm{Nm}^{61}$. Five groups hypothesis (Table 3) is considered and Palermo and Almería samples, which are adjacent to the tested oceanographic and geographic discontinuities, were also included. The proximity of nodes indicates more gene flow among them than with others, and the widths of arrows are proportional to relative migration values (threshold $=0.25$ ). For WM, all WM samples except those from Palermo and Almería were pooled. Region and location codes are given in Table 1.

species, such as Meganyctiphanes norvegica (euphasid) and Palaemon elegans (decapod) ${ }^{38,39}$, although it seems to cause no effect on other marine decapod species, including Perapenaeus longirostris (Penaoidea) ${ }^{26}$.

Although the Ibiza Channel and the Balearic front affected the decapod Liocarcinus depurator ${ }^{26}$ and littoral fish ${ }^{40}$, respectively, they had no effect on $A$. antennatus genetic structuring, confirming the results obtained using mtDNA ${ }^{2,10-12}$ and other microsatellite $\operatorname{loci}^{15}$. The detection of several larval stages of $A$. antennatus in this area $^{34-36}$ reinforce the hypothesis that larvae are passively transported by oceanic currents in most of the marine decapods $^{33}$, and justify the observed high degree at gene flow in the Western Mediterranean (Fig. 4, Table 4, Supplementary Fig. S3). The surface Northern Current and the circulation of deeper waters in the great cyclonic gyres of the WM, such as the Lion Gyre, could contribute to the horizontal and vertical population admixture in the WM Basin ${ }^{21,41}$. Moreover, periodical cascading events in the Gulf of Lion propagate shelf waters in submarine canyons at depths $>2,000 \mathrm{~m}^{1}$.

The Strait of Sicily acts as a weak geographic barrier to gene flow in many marine species ${ }^{18}$. Available studies using mitochondrial or microsatellite DNA markers suggested that this barrier limits gene flow between the EM and WM in the decapods Palinurus elephas and Crangon crangon ${ }^{28,29,31}$. In contrast, no differentiation was observed in Melicertus (Penaeus) kerathurus ${ }^{30}$. Our analysis showed genetic differentiation between the WM and EM (Table 2, Fig. 2), consistent with the mtDNA results reported for A. antennatus by Fernández et al. ${ }^{2}$. Nevertheless, in other mtDNA studies, with samples geographically closer to both sides of the Strait of Sicily, no differentiation in A. antennatus between the two Mediterranean basins was detected ${ }^{10,12}$. This observation is consistent with the IBD pattern that we observed in the Mediterranean Sea (Supplementary Fig. S4) and suggests that the Strait of Sicily is a more permeable barrier than the Strait of Gibraltar for A. antennatus, given that the former is much deeper $(360-430 \mathrm{~m})$ and wider $(130 \mathrm{~km})$ than the latter ${ }^{21}$. IBD signals along the WM-EM axis also have been detected in the decapod $P$. longirostris ${ }^{42}$. Thus, the EM stock of $A$. antennatus might be affected by adaptations to the Eastern Mediterranean Basin due to differences in environmental conditions from the Western Mediterranean Basin ${ }^{21}$.

The IO stock presented the greatest genetic distance (Table 2) and was the most geographically isolated (Fig. 1). Although more than 33 species of decapods, including penaeoid shrimps, display Lessepsian migration from Indian Ocean to the Mediterranean Sea ${ }^{43,44}$, our findings indicate that the IO stock of $A$. antennatus is genetically closer to the AO stock than to the Mediterranean ones (Table 2, Figs 2, 4). These results suggest that the Suez Canal, with only $26 \mathrm{~m}$ depth, the Bab-el-Mandeb Strait, $137 \mathrm{~m}$ deep in the shallowest section ${ }^{45}$, and the Red Sea, with lesser average depth than the Mediterranean $(450 \mathrm{~m} \text { vs. } 1,500 \mathrm{~m})^{21,45}$, prevent connectivity between the Mediterranean Sea and Indian Ocean populations, and the dispersal route of $A$. antennatus is more likely via the Atlantic Ocean than via the Red Sea. On the other hand, an open question is raised, applicable also to other demersal species for which little information is available, of how we may explain the scant presence of $A$. antennatus 
along the Atlantic Coast of Africa ${ }^{2}$. The species may have a "patchwork" distribution, or demersal populations may remain undiscovered.

In conclusion, using a set of sensitive microsatellite loci in A. antennatus, we were able to detect genetic differentiation and identify at least four genetic stocks and the signal for a fifth stock along the species' distribution. Our results support efforts to achieve sustainability of this resource for future generations via genetic assessment. Currently, overfishing strongly affects marine natural resources ${ }^{16}$. Taking into account genetic connectivity are fundamentally important to provide a basis for the study of $A$. antennatus resilience and adaptation to possible environmental changes from human impact ${ }^{46}$.

\section{Materials and Methods}

Sample sites. Samples were collected from 11 locations where A. antennatus is currently exploited across the following five regions: AO, AS, WM, EM, and IO. As the species is traditionally harvested in waters of the $\mathrm{WM}^{4}$, more locations from this region were included in the sampling design (Fig. 1, Table 1). In 2008, samples from AS, Almería, Sóller, Cabrera, and Mozambique were provided by various surveys conducted by the Spanish Institute of Oceanography, and samples from the Gulf of Lion and the Ionian Sea were provided by the Mediterranean International Bottom Trawl Survey (MEDITS08). The remaining samples were obtained by local fishermen and collected on the date of capture. Details of the samples are in Fernández et al. ${ }^{2}$. A piece of muscle from each of the 494 collected individuals was stored in 95\% ethanol for later DNA analysis.

DNA extraction and microsatellite genotyping. We performed genomic DNA extraction following the standard phenol-chloroform procedure, and we carried out genotyping for 12 microsatellites developed for $A$. antennatus: Aa123, Aa138, Aa496b, Aa667, Aa681, Aa751, Aa818, Aa956, Aa1061, Aa1195, Aa1255, and Aa1444, following Heras et al. ${ }^{13}$. These molecular markers were distributed in three multiplex PCRs (sets of 3-5 loci) and one singleplex PCR for optimal amplification, following standard procedures with an annealing temperature of $50^{\circ} \mathrm{C}$ or $60^{\circ} \mathrm{C}$, as described in Planella et al. ${ }^{22}$. PCR product sizing was performed with the GeneScan ${ }^{\mathrm{TM}} 500 \mathrm{LIZ}^{\circledR}$ size standard (Applied Biosystems) on an ABI PRISM ${ }^{\circledR} 3130$ Genetic Analyzer (Applied Biosystems). Allele scoring was performed with Geneious v. 7.1 .9 software $^{47}$.

Genetic diversity within locations and effective population size. We calculated allele number $(\mathrm{Na})$ and richness (Ar) per locus and per population with FSTAT v. 2.9.3.2 software $^{48}$, and computed the number of private alleles (Ap) with GenAlEx v. 6.503 software $^{49}$. We estimated observed and expected heterozygosities (Ho and $\mathrm{He}$ ), and inbreeding coefficient $F_{\mathrm{IS}}{ }^{50}$ and tested for linkage and HW equilibria using Genepop v. 4.4.3 software $^{51}$. We assessed test significance using exact tests (Markov chain Monte Carlo method with 10,000 dememorizations and 5,000 iterations) and Fisher's method for global tests. Significance values were adjusted for multiple comparisons using Bonferroni correction. Micro-Checker software ${ }^{52}$ was employed to identify scoring errors due to large allele drop-out, stuttering or presence of null alleles.

We estimated the contemporary effective population size $\left(N_{e}\right)$ for each location using NeEstimator v. 2.1 software ${ }^{19}$ with the Linkage Disequilibrium method under a random mating model, and we determined $95 \%$ confidence intervals using the non-parametric jack-knife method. Given the minimum sample size of 38 (Table 1), a critical allele frequency (Pcrit) of 0.01 was used to exclude alleles occurring in a single copy, ensuring that Pcrit $>1 / 2 \mathrm{~N}$.

Genetic differentiation between locations and gene flow. Pairwise $F_{\mathrm{ST}}$ values ${ }^{50}$ between locations were calculated using Arlequin v. 3.5.1.2 software ${ }^{53}$, with 10,000 permutations to test significance. We used the Bonferroni correction for multiple comparisons.

The FreeNA programme ${ }^{54}$ was used to assess the effect of null alleles when genetic differentiation $\left(F_{\mathrm{ST}}\right)$ was inferred. We estimated the frequency of null alleles and computed $F_{\mathrm{ST}}$ values that were and were not corrected for the presence of null alleles using 1,000 bootstrap replicates.

We conducted a global locus-by-locus AMOVA analysis with Arlequin v. 3.5.1.2 software ${ }^{53}$, computing $F$-statistics derived from hierarchical partitions. Four different a priori grouping scenarios were independently analyzed to test whether geographic and oceanographic discontinuities effectively reduced gene flow across the species distribution (Fig. 1, Table 3): (i) four groups based on previous mtDNA results, with the Strait of Gibraltar and Strait of Sicily acting and the sample from Mozambique Channel isolated from the others ${ }^{2}$; and (ii) additional groupings with modification of the effectiveness of various barriers. Statistical significance of $F$-statistics for each scenario was tested with 10,000 permutations. In such approach, the best grouping scenario maximizes $F_{\mathrm{CT}}$ by reducing $F_{\mathrm{SC}}$.

We used Populations v. 1.2.32 software ${ }^{55}$ to construct an NJ tree based on Latter's $F_{\text {ST }}$ genetic distance ${ }^{56}$. The robustness of the tree was tested using bootstrap analysis with 1,000 replicates. DAPC is a multivariate model-free type of analysis conducted with no assumption of $\mathrm{HW}$ or linkage equilibrium ${ }^{57}$. According to Pometti et al. ${ }^{58}$, it allows more rapid and accurate inference of $K$ populations than do Bayesian model-based clustering methods. We conducted DAPC with adegenet v. $2 \cdot 1 \cdot 0^{59}$ to identify genetic clusters among sampled individuals. We also computed membership probabilities based on the retained discriminant functions, and we used a compoplot function to interpret group memberships in DAPC and to infer admixture between clusters.

IBD was tested with the ISOLDE programme in Genepop v. 4.4.3 ${ }^{51}$. We used the Mantel test based on 100,000 permutations and correlated the logarithm of the pairwise geographical distances between locations and pairwise estimates of linearized $F_{\mathrm{ST}}\left[F_{\mathrm{ST}} /\left(1-F_{\mathrm{ST}}\right)\right]$, obtained with FreeNA. The geographical distances between sampling sites were measured as the shortest marine map distance (in kilometers) in Google Earth based on two hypothesised dispersal routes: (i) that connecting Mozambique with Atlantic populations through the Cape of Good 
Hope and along the Atlantic coast of Africa, and (ii) passage through the Red Sea and Suez Canal, and then through the Mediterranean Sea.

Finally, we generated a network graph representing relative directional migration rates between regions, considering the locations adjoining the oceanographic barriers, with divMigrate-online ${ }^{60}$ (https://popgen.shinyapps. io/divMigrate-online/) using $\mathrm{Nm}^{61}$ as a measure of genetic distance. Population samples (or groups of samples) are represented by nodes in the networks. In addition, to test whether the gene flow among regions was asymmetrically significant, 1,000 bootstrap replicates were performed $(\alpha=0.05)$.

\section{Data Availability}

All data are included in the article.

\section{References}

1. Sardà, F., Roldán, M. I., Heras, S. \& Maltagliati, F. Influence of the genetic structure of the red and blue shrimp, Aristeus antennatus (Risso, 1816), on the sustainability of a deep-sea population along a depth gradient in the western Mediterranean. Sci. Mar. 74, 569-575 (2010).

2. Fernández, M. V., Heras, S., Maltagliati, F., Turco, A. \& Roldán, M. I. Genetic structure in the blue and red shrimp Aristeus antennatus and the role played by hydrographical and oceanographical barriers. Mar. Ecol. Prog Ser. 421, 163-171 (2011).

3. Sardà, F. et al. Deep-sea distribution, biological and ecological aspects of Aristeus antennatus (Risso, 1816) in the western and central Mediterranean Sea. Sci. Mar. 68, 117-127 (2004).

4. FAO (Food and Agriculture Organization). Species fact sheets. Available from, http://www.fao.org/fishery/species/3422/en (2018).

5. FAO (Food and Agriculture Organization). General Fisheries Commission for the Mediterranean; Report of the ninth session of the Scientific Advisory Committee. FAO Fish. Rep. 814. Available from, http://www.fao.org/3/a-a0889b.pdf (2006).

6. Figuereido, M. J., Figuereido, I. \& Machado, P. B. Deep-water penaeid shrimps (Crustacea: decapoda) from off the portuguese continental slope: an alternative future resource? Fish. Res. 51, 321-326 (2001).

7. Sobrino, I., Dias, N., Muñoz, I., Salmerón, F. \& Varela, D. Distribution patterns and biological characteristics of Aristeus antennatus (Risso, 1816) and Aristeus virilis (Bate, 1881) in Mozambique Waters of the Western Indian Ocean. Western Indian Ocean J. Mar. Sci. 8, 49-59 (2009).

8. FAO (Food and Agriculture Organization). Report of the expert consultation on utilization and conservation of aquatic genetic resources. FAO Fish. Rep. 491 (1993).

9. Bensch, A., Gianni, M., Gréboval, D., Sanders, J. \& Hjort, A. Worldwide review of bottom fisheries in the high seas. FAO Fisheries and Aquaculture Technical Paper. No. 522, Rev. 1, http://www.fao.org/tempref/docrep/fao/012/i1116e/i1116e.pdf (2009).

10. Maggio, T., Lo Brutto, S., Cannas, R., Deiana, A. M. \& Arculeo, M. Environmental features of deep-sea habitats linked to the genetic population structure of a crustacean species in the Mediterranean Sea. Mar. Ecol. 30, 354-365 (2009).

11. Roldán, M. I., Heras, S., Patellani, R. \& Maltagliati, F. Analysis of genetic structure of the red shrimps Aristeus antennatus from the western Mediterranean employing two mitochondrial regions. Genetica 136, 1-4 (2009).

12. Marra, A., Mona, S., Sà, R. M., D’Onghia, G. \& Maiorano, P. Population genetic history of Aristeus antennatus (Crustacea: Decapoda) in the Western and Central Mediterranean Sea. PLoS One 10, e0117272 (2015).

13. Heras, S. et al. Development and characterization of novel microsatellite markers by Next Generation Sequencing for the blue and red shrimp Aristeus antennatus. PeerJ 4, e2200 (2016).

14. Cannas, R. et al. Isolation and characterization of 14 polymorphic microsatellite markers for the blue and red shrimp, Aristeus antennatus (Crustacea, Decapoda). Mol. Ecol. Resour. 8, 1420-1422 (2008).

15. Cannas, R. et al. Genetic variability of the blue and red shrimp Aristeus antennatus in the Western Mediterranean Sea inferred by DNA microsatellite loci. Mar. Ecol. 33, 350-363 (2012).

16. Pinsky, M. L. \& Palumbi, S. R. Meta-analysis reveals lower genetic diversity in overfished populations. Mol. Ecol. 23, 29-39 (2014).

17. Patarnello, T., Volckaert, F. A. M. J. \& Castilho, R. Pillars of Hercules: is the Atlantic-Mediterranean transition a phylogeographical break? Mol. Ecol. 16, 4426-4444 (2007).

18. Pascual, M., Rives, B., Schunter, C. \& Macpherson, E. Impact of life history traits on gene flow: A multispecies systematic review across oceanographic barriers in the Mediterranean Sea. PLoS One 12, e0176419 (2017).

19. Do, C. et al. NeEstimator v2: re-implementation of software for the estimation of contemporary effective population size (Ne) from genetic data. Mol. Ecol. Resour. 14, 209-214 (2014)

20. Cannas, R., Marcia, S., Sacco, F., Cau, A. \& Deiana, A. M. First isolation and characterization of genomic SSR markers for the giant red shrimp Aristaeomorpha foliacea (Risso, 1827). Genet. Mol. Res. 11, 2745-2748 (2012).

21. Rohling, E. J., Abu-Zied, R., Casford, J. S. L., Hayes, A. \& Hoogakker, B. A. A. The Marine Environment: Present and Past in The Physical Geography of the Mediterranean (ed. Woodward, J.) 33-67 (Oxford University Press, 2009).

22. Planella, L., Manuel, V., García-Marín, J. L., Heras, S. \& Roldán, M. I. Mating structure of the blue and red shrimp, Aristeus antennatus (Risso, 1816) characterized by relatedness analysis. Sci. Rep. 9, 7227 (2019).

23. Franklin, I. R. Evolutionary change in small populations in Conservation Biology: an Evolutionary-Ecological Perspective (eds Soulé, M. E. \& Wilcox, B. A.) 135-150 (Sinauer Associates, 1980).

24. Waples, R. S. Separating the wheat from the chaff: patterns of genetic differentiation in high gene flow species. J. Hered. 89, 438-450 (1998).

25. Cano, J. M., Shikano, T., Kuparinen, A. \& Merilä, J. Genetic differentiation, effective population size and gene flow in marine fishes: implications for stock management. J. Integr. Field Sci. 5, 1-10 (2008).

26. García-Merchán, V. H. et al. Phylogeographic patterns of decapod crustaceans at the Atlantic-Mediterranean transition. Mol. Phylogenet. Evol. 62, 664-672 (2012).

27. Palmas, F., Olita, A., Addis, P., Sorgente, R. \& Sabatini, A. Modelling giant red shrimp larval dispersal in the Sardinian seas: density and connectivity scenarios. Fish. Oceanogr. 26, 364-78 (2017).

28. Palero, F., Abelló, P., Macpherson, E., Gristina, M. \& Pascual, M. Phylogeography of the european spiny lobster (Palinurus elephas): influence of current oceanographical features and historical processes. Mol. Phylogenet. Evol. 48, 708-717 (2008).

29. Luttikhuizen, P. C., Campos, J., van Bleijswijk, J., Peijnenburg, K. T. C. A. \& van der Veer, H. W. Phylogeography of the common shrimp, Crangon crangon (L.) across its distribution range. Mol. Phylogenet. Evol. 46, 1015-1030 (2008).

30. Pellerito, R., Arculeo, M. \& Bonhomme, F. Recent expansion of Northeast Atlantic and Mediterranean populations of Melicertus (Penaeus) kerathurus (Crustacea: Decapoda). Fish. Sci. 75, 1089-1095 (2009).

31. Palero, F., Abelló, P., Macpherson, E., Beaumont, M. \& Pascual, M. Effect of oceanographic barriers and overfishing on the population genetic structure of the European spiny lobster (Palinurus elephas). Biol. J. Linn. Soc. 104, 407-418 (2011).

32. Lo Brutto, S., Maggio, T., Deiana, A. M., Cannas, R. \& Arculeo, M. Further investigations on populations of the deep-water blue and red shrimp Aristeus antennatus (Risso, 1816) (Decapoda, Dendrobranchiata), as inferred from amplified fragment length polymorphism (AFLP) and mtDNA analyses. Crustaceana 85, 1393-1408 (2012).

33. Anger, K. Contributions of larval biology to crustacean research: a review. Invertebr. Reprod. Dev. 49, 175-205 (2006). 
34. Carbonell, A., Dos Santos, A., Alemany, F. \& Vélez-Belchi, P. Larvae of the red shrimp Aristeus antennatus (Decapoda: Dendrobranchiata: Aristeidae) in the Balearic Sea: new occurrences fifty years later. Mar. Biodiv. Rec. 3, e103 (2010).

35. Torres, A. P., Dos Santos, A., Alemany, F. \& Massutí, E. Larval stages of crustacean species of interest for conservation and fishing exploitation in the western Mediterranean. Sci. Mar. 77, 149-160 (2013).

36. Carreton, M. et al. Morphological identification and molecular confirmation of the deep-sea blue and red shrimp Aristeus antennatus larvae. PeerJ 7, e6063 (2019).

37. Tintoré, J., La Violette, P. E., Blade, I. \& Cruzado, A. A study of an intense density front in the eastern Alboran Sea: the Almeria-Oran front. J. Phys. Oceanogr. 18, 1384-1397 (1988).

38. Papetti, C., Zane, L., Bortolotto, E., Bucklin, A. \& Patarnello, T. Genetic differentiation and local temporal stability of population structure in the euphausiid Meganyctiphanes norvegica. Mar. Ecol. Prog. Ser. 289, 225-235 (2005).

39. Reuschel, S., Cuesta, J. A. \& Schubart, C. D. Marine biogeographic boundaries and human introduction along the European coast revealed by phylogeography of the prawn Palaemon elegans. Mol. Phylogenet. Evol. 55, 765-775 (2010).

40. Galarza, J. A. et al. The influence of oceanographic fronts and early-life-history traits on connectivity among littoral fish species. Proc. Natl. Acad. Sci. USA 106, 1473-1478 (2009).

41. Orsi Relini, L., Mannini, A. \& Relini, G. Updating knowledge on growth, population dynamics, and ecology of the blue and red shrimp, Aristeus antennatus (Risso, 1816), on the basis of the study of its instars. Mar. Ecol. 34, 90-102 (2013).

42. Lo Brutto, S., Maggio, T. \& Arculeo, M. Isolation By Distance (IBD) signals in the deep-water rose shrimp Parapenaeus longirostris (Lucas, 1846) (Decapoda, Panaeidae) in the Mediterranean Sea. Mar. Environ. Res. 90, 1-8 (2013).

43. FAO (Food and Agriculture Organization). Report of the Sub-Regional Technical meeting on the Lessepsian migration and its impact on Eastern Mediterranean fishery. EastMed Technical Documents 4. Available from, http://www.fao.org/3/a-ap961e.pdf (2010).

44. Levitt, Y., Grave, S. \& Shenkar, N. First record of an invasive shrimp from the family Processidae (Crustacea, Decapoda) in the Mediterranean Sea. Mediterr. Mar. Sci. 15, 650-653 (2014).

45. Siddall, M., Smeed, D. A., Matthiesen, S. \& Rohling, E. J. Modelling the seasonal cycle of the exchange flow in Bab el Mandab (Red Sea). Deep Sea Res. Part I Oceanogr. Res. Pap. 49, 1551-1569 (2002).

46. Waples, R., Punt, A. \& Cope, J. Integrating genetic data into management of marine resources: how can we do it better. Fish Fish. 9 , 423-449 (2008)

47. Kearse, M. et al. Geneious Basic: an integrated and extendable desktop software platform for the organization and analysis of sequence data. Bioinformatics 28, 1647-1649 (2012).

48. Goudet, J. FSTAT, a program to estimate and test gene diversities and fixation indices (version 2.9.3). Available from, https://www2. unil.ch/popgen/softwares/fstat.htm (2001)

49. Peakall, R. \& Smouse, P. E. GenAlEx 6.5: genetic analysis in Excel. Population genetic software for teaching and research - an update. Bioinformatics 28, 2537-2539 (2012).

50. Weir, B. S. \& Cockerham, C. C. Estimating F-statistics for the analysis of population structure. Evolution 38, 1358-1370 (1984).

51. Rousset, F. Genepop'007: a complete re-implementation of the Genepop software for Windows and Linux. Mol. Ecol. Resour. 8, 103-106 (2008).

52. Van Oosterhout, C., Hutchinson, W. F., Wills, D. P. M. \& Shipley, P. Micro-Checker: software for identifying and correcting genotyping errors in microsatellite data. Mol. Ecol. Notes 4, 535-538 (2004).

53. Excoffier, L. \& Lischer, H. E. L. Arlequin suite ver 3.5: a new series of programs to perform population genetics analyses under Linux and Windows. Mol. Ecol. Resour. 10, 546-67 (2010).

54. Chapuis, M. P. \& Estoup, A. Microsatellite null alleles and estimation of population differentiation. Mol. Biol. Evol. 24, 621-631 (2007).

55. Langella, O. Populations 1.2.32: Population genetic software (individuals or population distances, phylogenetic trees). Available from, http://www.bioinformatics.org/project/?group id=84 (2011).

56. Latter, B. D. H. Selection in finite populations with multiple alleles. III. Genetic divergence with centripetal selection and mutation. Genetics 70, 475-490 (1972).

57. Jombart, T., Devillard, S. \& Balloux, F. Discriminant analysis of principal components: a new method for the analysis of genetically structured populations. BMC Genet. 11, 94 (2010).

58. Pometti, C. L., Bessega, C. F., Saidman, B. O. \& Vilardi, J. C. Analysis of genetic population structure in Acacia caven (Leguminosae, Mimosoideae), comparing one exploratory and two Bayesian-model-based methods. Genet. Mol. Biol. 37, 64-72 (2014).

59. Jombart, T. Adegenet: a R package for the multivariate analysis of genetic markers. Bioinformatics 24, 1403-1405 (2008).

60. Sundqvist, L., Keenan, K., Zackrisson, M., Prodohl, P. \& Kleinhans, D. Directional genetic differentiation and relative migration. Ecol. Evol. 6, 3461-3475 (2016).

61. Alcala, N., Goudet, J. \& Vuilleumier, S. On the transition of genetic differentiation from isolation to panmixia: what we can learn from $\mathrm{G}_{\mathrm{ST}}$ and D. Theor. Popul. Biol. 93, 75-84 (2014).

\section{Acknowledgements}

This work was supported by grants to M.I.R. by the Spanish Ministerio de Educación y Ciencia (CTM200600785) and Spanish Ministerio de Economia y Competitividad (CTM2014-54648-C2-2-R). Additional support to S.H by PADI foundation. L.P. benefited from a predoctoral fellowship from the University of Girona (BR2014).

\section{Author Contributions}

S.H. and M.I.R. conceived and designed the study. S.H. and L.P. performed the laboratory work. S.H. and J.L.G.-M. analyzed the data. M.V. contributed to data interpretation. S.H. took the lead in writing the manuscript with input from all authors.

\section{Additional Information}

Supplementary information accompanies this paper at https://doi.org/10.1038/s41598-019-49958-5.

Competing Interests: Aristeus antennatus image in Fig. 1 was taken by Francesc Rabat.

Publisher's note Springer Nature remains neutral with regard to jurisdictional claims in published maps and institutional affiliations. 
(c) (i) Open Access This article is licensed under a Creative Commons Attribution 4.0 International License, which permits use, sharing, adaptation, distribution and reproduction in any medium or format, as long as you give appropriate credit to the original author(s) and the source, provide a link to the Creative Commons license, and indicate if changes were made. The images or other third party material in this article are included in the article's Creative Commons license, unless indicated otherwise in a credit line to the material. If material is not included in the article's Creative Commons license and your intended use is not permitted by statutory regulation or exceeds the permitted use, you will need to obtain permission directly from the copyright holder. To view a copy of this license, visit http://creativecommons.org/licenses/by/4.0/.

(C) The Author(s) 2019 